\title{
ACE-RELATED CHANGES IN ANTIOXIDANT ENZYME ACTIVITIES, FATTY ACID COMPOSITION AND LIPID PEROXIDATION IN WHOLE BODY GAMMARUS LOCUSTA (CRUSTACEA: AMPHIPODA)
}

Ana D. Correia ${ }^{a^{*}}$, M. Helena Costa ${ }^{a}$, Orlando J. Luis ${ }^{b}$ and David R. Livingstone ${ }^{c}$

${ }^{a}$ IMAR- Instituto do Mar. Departamento de Ciências e Engenharia do Ambiente, Faculdade de Ciências e Tecnologia, Universidade Nova de Lisboa, 2829-516 Caparica, Portugal. Phone: (351) 212948300, Fax: (351) 212948554.

${ }^{\mathrm{b}}$ Departamento de Zoologia, Universidade de Lisboa, Laboratório Marítimo da Guia, Estrada do Guincho, 2750 Cascais, Portugal.

cPlymouth Marine Laboratory. Prospect Place, West Hoe, Plymouth, Devon PL1 3DH. United Kingdom.

Figures: 2

Tables: 2

*Corresponding author: Correia A.D . IMAR- Instituto do Mar. DCEA., Fac. Ciências.Tecnol. Univ. Nova de Lisboa, 2829-516 Caparica, Portugal, email: adc@fct.unl.pt 


\section{Abstract}

The main aim of this work was to provide baseline data on aspects of prooxidant and antioxidant processes in different life-stages of the marine amphipod Gammarus locusta. The activities of antioxidant enzymes and levels of lipid peroxidation were determined in whole body juveniles, sub-adults and male and female

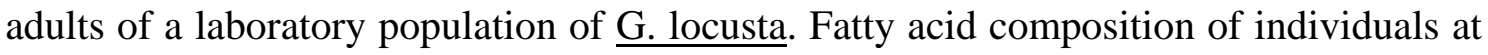
these different stages of development was also characterised in order to examine the contribution that polyunsaturated fatty acids (PUFA) might make to the peroxidation status of animals. The antioxidant enzymes, measured in whole body 100, 000 supernatants, comprised catalase (CAT, EC 1.11.1.6), superoxide dismutase (SOD; EC 1.15.1.1) and glutathione peroxidase (GPX; EC 1.11.1.9). Fatty acids were analysed as fatty acid methyl esters (FAME). Lipid peroxidation was examined in terms of the levels of lipid peroxides determined as thiobarbituric acid-reactive malondialdehyde equivalents. Age-related changes were seen in antioxidant enzyme status: levels of SOD $(\mathrm{p}<0.01)$ and GPX $(\mathrm{p}<0.001)$ activities decreased progressively during development from juveniles to adults. Sex-related changes in GPX activity were also seen, the levels being higher in adult males than females $(\mathrm{p}<0.001)$. The amount of FAME present in whole body amphipod also changed over the life span. Among PUFA, the eicosapentaenoic (C20:5n-3), arachidonic (C20:4n-6) and docosahexaenoic acids (C22:6n-3) were the most abundant acids in this species, and both their individual concentrations and total PUFA increased progressively with age (up to 3.3-fold; $\mathrm{p}<$ 0.001). The latter changes may contribute to the explanation of the observed differences in peroxidation status of the animals with age; thus, levels of lipid peroxides increased up to $40 \%$ in adult males compared to other age-classes $(\mathrm{p}<0.001)$. Overall, the decline in antioxidant enzyme activities, coupled with increased levels of PUFA, as the 
individual grows older, may render the older animals more susceptible to lipid peroxidation and oxidative stress. 
Keywords: Antioxidant enzymes; Lipid peroxidation; Polyunsaturated fatty acids; Oxidative stress; Amphipod; Life-stage; Gammarus locusta 
Abbreviations: CAT, catalase; FAME, fatty acid methyl esters; GPX, glutathione peroxidase; MDA, malondialdehyde; MT, metallothionein; PUFA, polyunsaturated fatty acids; ROS, reactive oxygen species; SOD, superoxide dismutase. 


\section{Introduction}

Aquatic life is currently being exposed to chemical contamination by an increasing variety of anthropogenic activities that can induce many different mechanisms of toxicity, each contributing to varying degrees to the final overall deleterious effect (Di Giulio et al., 1995; Livingstone, 2001). Consequently, in environmental disturbance assessment, the integration of chemical data with biological responses (so-called biomarkers) is strongly recommended in order to assess effects of pollutants on the organisms (Besten, 1998). Biomarkers can be developed for application at different levels of biological organisation. At the biochemical level, they include studies on the enhanced production of reactive oxygen species (ROS) as a general pathway of toxicity induced by many contaminants, leading to a condition of oxidative stress (Di Giulio et al., 1995; Livingstone, 2001). These ROS include superoxide anion radical $\left(\mathrm{O}_{2}{ }^{-}\right)$, hydrogen peroxide $\left(\mathrm{H}_{2} \mathrm{O}_{2}\right)$ and the highly reactive hydroxyl radical $(\mathrm{OH} \cdot)$.

As a consequence of the reactivity of ROS and their potential to damage cells and tissues, marine and other organisms balance the production of these radicals with a wide variety of cellular antioxidant defences. Prominent among these antioxidants are the enzymes superoxide dismutase (SOD, EC 1.15.1.1 - converts $\mathrm{O}_{2} \cdot{ }^{-}$to $\mathrm{H}_{2} \mathrm{O}_{2}$ ), catalase (CAT; EC 1.11.1.6 - converts $\mathrm{H}_{2} \mathrm{O}_{2}$ to water) and glutathione peroxidase (GPX; EC 1.11.1.9 - detoxifies $\mathrm{H}_{2} \mathrm{O}_{2}$ and organic hydroperoxides produced, for example, by lipid peroxidation) (Di Giulio et al., 1995; Halliwell and Gutteridge, 1999). Antioxidant enzymes can be induced by various environmental pro-oxidant conditions (i.e. increased ROS generation), e.g. exposure to various types of pollution, as well as being affected by other endogenous/exogenous factors, such as age (Viarengo et al., 1991b; Hole et al., 1993; Peters and Livingstone, 1996; Arun and Subramanian, 1998), diet (Peters et al., 1994), seasonality/reproductive cycle (Viarengo et al., 1991a; Solé et al., 1995; 
Ringwood and Conners, 2000), temperature (Buchner et al., 1996; Abele et al., 1998) and hypoxia/hyperoxia (Abele-Oeschger et al., 1994; Abele-Oeschger and Oeschger, 1995).

In normal metabolism (i.e. without the influence of stress conditions), a balance exists between the generation of ROS and other pro-oxidants, and their detoxication and removal by antioxidant defence mechanisms (Winston and Di Giulio, 1991). However, either an increase in ROS production above the level that can be removed by antioxidant defences, or a decrease in the capacity of the antioxidant defences, could result in oxidative damage to key molecules, including DNA, protein and lipids (lipid peroxidation) (Halliwell and Gutteridge, 1999). A number of studies have demonstrated potential for ROS generation; antioxidant enzyme and free radical scavenger responses; and oxidative damage in species of invertebrate, mainly in molluscs (review by Di Giulio et al., 1995; Livingstone et al., 2000; Livingstone, 2001). However, few studies have been undertaken on crustaceans, and little is known about such mechanisms, in particular in amphipods. The latter is of interest because such animals have a number of characteristics, such as sensitivity to environmental disturbance, short life cycle in temperate and tropical regions, and amenability to experimental investigation that make them ideal for ecotoxicological studies (De Witt et al., 1992; Reish, 1993; Costa and Costa, 2000).

Our own research has focused on the development of biochemical markers in a marine amphipod species, Gammarus locusta (Gammaridae, Linnaeus, 1758). Recent studies have demonstrated that metallothionein (MT), which can have both metal-

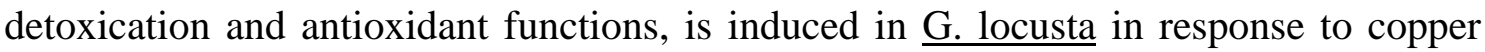
exposure (Correia et al., 2001, Correia et al., 2002a,b). Antioxidant enzymes are an important protective mechanism against ROS and, like many other biochemical systems, their effectiveness may vary with the stage of development and other 
physiological aspects of the organism (Halliwell and Gutteridge, 1999; Livingstone, 2000). Little is known about such processes in amphipods. In Mytilus sp., however, increased susceptibility to oxidative damage (measured as lipid peroxidation) has been observed with increasing age, concomitant with decreasing levels of antioxidant defences (Viarengo et al. 1991b; Hole et al., 1993). A second important factor affecting the potential for oxidative damage is the level of the target molecules, e.g. polyunsaturated fatty acids (PUFA) are readily oxidized by ROS to lipid peroxides (Di Giulio et al., 1995), and account for a significant percentage of membrane phospholipids in amphipods (Clarke et al., 1985; Kawashima et al., 1999). Thus, the incidence of lipid peroxidation may depend upon both the level of antioxidant enzymes and the composition of fatty acids in the organisms, the latter of which may also change with aspects of the animal's physiology, including development, age and sex (Parihar and Dubey, 1995).

Both the development of (molecular) biomarkers (Livingstone et al., 2000) and understanding of basic pro-oxidant/antioxidant processes (Livingstone, 2001) require knowledge of how the biochemical systems are influenced by key exogenous/endogenous factors such as developmental stage, age and sex. The current study describes the variation in whole body antioxidant enzymes activities, lipid peroxidation (total lipid peroxides measured as thiobarbituric acid-reactive substances) and fatty acid composition over the lifetime (juveniles, sub-adults and male and female adults) of $\underline{G}$. locusta. Fatty acids were analysed as fatty acid methyl esters (FAME). The results are discussed in relation to age and sex-dependent changes in pro-oxidant and antioxidant processes in this species. 


\section{Material and Methods}

\section{Chemicals}

Dithiothreitol (DTT), phenylmethylsulfonyl fluoride (PMSF), xanthine oxidase (EC 1.2.3.2), horse heart cytocrome c, hypoxanthine, sodium azide, reduced glutathione (GSH), glutathione reductase (EC 1.6.4.2), $\mathrm{H}_{2} \mathrm{O}_{2}$, ß-nicotinamide adenine dinucleotide phosphate (NADPH) and dodecanoic acid 4-nitrophenyl ester $\left(\mathrm{C}_{18} \mathrm{H}_{27} \mathrm{NO}_{4}\right)$ were obtained from Sigma Chemical Co., Portugal. All other chemicals were analytical grade and were from Merck, Portugal.

\section{Animals}

Animals were obtained from laboratory cultures. In the culture, they were kept under conditions of room temperature $\left(15 \pm 1{ }^{\circ} \mathrm{C}\right)$ and a $12-\mathrm{h}$ light/dark photoperiod, and held in plastic microcosms containing $0.45 \mu \mathrm{m}$ filtered seawater (33 $\pm 1 \%$ o salinity) and a sediment layer of up to $1 \mathrm{~cm}$. Aeration was provided by plastic pipette tips placed at least $1 \mathrm{~cm}$ above the sediment surface. Dissolved oxygen in the overlying water was at least $8 \mathrm{mg} / \mathrm{L}$. To provide shelter and mimic the natural environment, small stones were placed in the microcosms. The food consists mainly on Ulva lactuca and Ulva rigida. The macroalgae and sediment (sand with $0.5 \%$ fine fraction and $0.9 \%$ total volatile solids) were collected from an unpolluted area, located on the South margin of Sado estuary, Portugal $\left(38^{\circ} 27^{\prime} \mathrm{N}, 08^{\circ} 43^{\prime} \mathrm{W}\right)$ that is the natural site of the G. locusta population, commonly used in the laboratory studies. This site is free of direct influence of effluents discharge, which is confined to the North margin, and it contains a rich zoobenthic community (Mucha and Costa, 1999). Sediment from this location is known not to be contaminated and is used as control sediment in ecotoxicological studies (Costa et al., 1998). Animals were starved for $24 \mathrm{~h}$ prior to being gently separated 
through a battery of screens of decreasing mesh size (1500, 1000 and $475 \mu \mathrm{m}$ ), distributing the amphipods into three size-classes: $>7 \mathrm{~mm}, 5-8 \mathrm{~mm}$ and 2-5 mm length, respectively. These likely mainly correspond to the age-classes: adults (> 7 weeks-old), sub-adults (4 to 7 weeks-old) and juveniles (1 to 4 weeks-old), respectively (Costa et al., 1998). Pools of whole animal ( $\geq 50$ animals) at any stage of the moult cycle were divided into 3 or 5 batches. Adult males and females were sampled separately. Females were isolated from the culture until ovarian development and spawning occurred before being used. All pooled samples were frozen in liquid nitrogen and stored at $-80{ }^{\circ} \mathrm{C}$ prior to the biochemical analyses.

\section{Antioxidant enzymes analyses}

Sample preparation

Preliminary studies were performed in order to optimise the methodology involving the use of whole body amphipod in the biochemical assays. All procedures were performed at $4{ }^{\circ} \mathrm{C}$. Pools of whole animal (pool wet wt. $\sim 0.8-1.0 \mathrm{~g}$ ) were homogenised in $50 \mathrm{mM} \mathrm{KH} \mathrm{PO}_{4} / \mathrm{K}_{2} \mathrm{HPO}_{4}$, $\mathrm{pH} 7.8$ containing 2 mM EDTA in a PotterElvehijm homogeniser, using a wet wt./buffer volume ratio of 1:2. The homogenation buffer also contained 1mM DTT and $100 \mathrm{mM}$ PMSF in the case of samples used for measurement of CAT activity. Homogenates were centrifuged at $1500 \mathrm{x}$ g for $15 \mathrm{~min}$ and the resulting supernatant centrifuged at 100, $000 \mathrm{x}$ g for $90 \mathrm{~min}$. CAT, SOD and GPX activities were measured in the $100,000 \mathrm{~g}$ supernatant (i.e. cytosolic) fraction of the whole organisms. 
Biochemical assays

Enzyme activities were measured using a dual-beam spectrophotometer (Unicam UV 5-120) at $25 \pm 0.5^{\circ} \mathrm{C}$. Assays were run at least in duplicate. CAT activity was measured by the decrease in absorbance at $240 \mathrm{~nm}$ due to $\mathrm{H}_{2} \mathrm{O}_{2}$ consumption (extinction coeff. $36 \mathrm{mM}^{-1} \mathrm{~cm}^{-1}$ ) according to Aebi (1974). The reaction volume was $3 \mathrm{ml}$ and

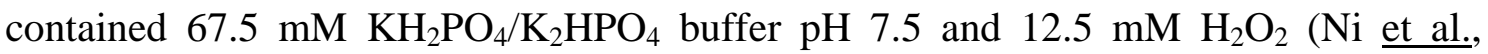
1990). The reaction was started by the addition of the sample.

SOD activity was determined by an indirect method involving the inhibition of cytocrome c reduction. In this method, SOD competes with cytochrome c for $\mathrm{O}_{2}{ }^{-}$ generated by the hypoxanthine and xanthine oxidase reaction. The reduction of cytochrome c by $\mathrm{O}_{2} \cdot{ }^{-}$is monitored by the absorbance increase at $550 \mathrm{~nm}$ (McCord and Fridovich, 1969). The reaction volume was $3 \mathrm{ml}$ and contained $50 \mathrm{mM}$ $\mathrm{KH}_{2} \mathrm{PO}_{4} / \mathrm{K}_{2} \mathrm{HPO}_{4}$ buffer $\mathrm{pH}$ 7.8, $0.1 \mathrm{mM}$ EDTA, 50 $\mu \mathrm{M}$ hypoxanthine, $5.6 \mathrm{mU}$ xanthine oxidase and $10 \mu \mathrm{M}$ cytocrome c (Livingstone et al., 1990). The results of this enzymatic assay are given in units of SOD activity per milligram protein $\left(\mathrm{U} \mathrm{mg}^{-1}\right)$, where one unit of SOD is defined as the amount of sample causing $50 \%$ inhibition of cytochrome c reduction.

GPX activity was measured with $\mathrm{H}_{2} \mathrm{O}_{2}$ as substrate, i.e. the activity of the selenium (Se)-containing GPX (Halliwell and Gutteridge, 1999). The activity was monitored by following the decrease in NADPH concentration (at $340 \mathrm{~nm}$ ), which is consumed during the generation of GSH from oxidized glutathione (extinction coeff. $6.2 \mathrm{mM}^{-1} \mathrm{~cm}^{-1}$ ), according to Günzler and Flohe (1985). This assay requires the use of a reference cell without sample added. The chemical rate of NADPH loss determined in the absence of the sample was subtracted from the total rate (Livingstone et al., 1992). The activity of this enzyme was determined under the conditions of $50 \mathrm{mM}$ $\mathrm{KH}_{2} \mathrm{PO}_{4} / \mathrm{K}_{2} \mathrm{HPO}_{4}$ buffer $\mathrm{pH}$ 7.0, $2 \mathrm{mM}$ GSH, $0.5 \mathrm{mM}$ sodium azide, $2 \mathrm{U}$ glutathione 
reductase, $0.12 \mathrm{mM} \mathrm{NADPH}, 0.2 \mathrm{mM} \mathrm{H}_{2} \mathrm{O}_{2}, 100 \mu \mathrm{l}$ sample and water to give a final reaction volume of $1 \mathrm{ml}$ (Livingstone et al., 1990).

Total protein was measured according to the method of Bradford (1976) using bovine serum albumin as standard.

\section{Fatty acid analyses}

Lipids were extracted from lyophilised samples of whole body amphipods (pool wet weight $1.0 \mathrm{~g}, \mathrm{n}=3)$ by homogenisation in methanol/chloroform/water $(2: 2: 1.8, \mathrm{v} / \mathrm{v})$ (Bligh and Dyer, 1959). The homogenate was filtered through a Büchner funnel with slight suction before centrifugation at 5,000 x g for $4 \mathrm{~min}$. The lower chloroform phase was evaporated and the pure lipid residue or total lipids weighted (the total lipid content was expressed as percentage of whole body wet weight). All evaporations of solvents were carried out in a water bath at $30{ }^{\circ} \mathrm{C}$, first under vacuum then under a stream of nitrogen. The lipid extracts were saponified for 45 min under nitrogen at $100{ }^{\circ} \mathrm{C}$ with $0.5 \mathrm{M} \mathrm{KOH}$ in methanol in conjunction with added $100 \mu \mathrm{l}$ of internal standard fatty acid (C19:0). The resultant fatty acids were recovered and their methyl esters prepared by reaction with $14 \% \mathrm{BF}_{3} / \mathrm{CH}_{3} \mathrm{OH}$ solution for 8 min at $100{ }^{\circ} \mathrm{C}$ under nitrogen (Metcalfe and Schmitz, 1961). The FAME, after solvent evaporation, were finally recovered in 2 ml isooctane. They were analysed by high-resolution capillary gas-chromatography (Varian 3300 Star 3400 CX) using a split 10:1 and separated on a $30 \mathrm{~m}$ fused silica WCOT SP1000 capillary. Analytical conditions were $1 \mathrm{ml} \mathrm{min}^{-1}$ helium carrier gas, at a temperature of $180{ }^{\circ} \mathrm{C}$ for $7 \mathrm{~min}$ and then programmed at a rate of $4{ }^{\circ} \mathrm{C} \min ^{-1}$ to $210{ }^{\circ} \mathrm{C}$. Injector port and FID were kept at $250{ }^{\circ} \mathrm{C}$. Column performance was monitored by routine injection of a secondary standard of fatty acid methyl esters prepared from codliver oil (with added nonadecanoid acid as internal standard). 
Fatty acids were identified by co-chromatography with standards and, in addition, the peaks of chromatograms were compared with those of the methyl esters prepared from cod-liver oil reference standard (Ackman et al., 1967). Peak areas were measured by a computer program (Star Chromatography Workstation) installed in a IBM PS/1 and were also expressed as $\mu \mathrm{g}$ of fatty acid $\mathrm{mg}^{-1}$ dry wt. by calculation against the area of the internal standard.

\section{Lipid peroxide analyses}

Pools of whole animal (0.05 - 0.08 g wet wt) were homogenised at $4{ }^{\circ} \mathrm{C}$ in $1: 4$ wet wt./buffer volume ratio in $50 \mathrm{mM} \mathrm{NaH} \mathrm{PO}_{2} / \mathrm{Na}_{2} \mathrm{HPO}_{4}$ buffer $\mathrm{pH}$ 7.4, containing 15 $\%$ glycerol $(\mathrm{w} / \mathrm{v})$, and centrifuged at $9000 \mathrm{x}$ g for $15 \mathrm{~min}$ at $4{ }^{\circ} \mathrm{C}$. Lipid peroxide was measured in sample supernatants by the generation of thiobarbituric acid reactive species (TBARS) and quantified in terms of malondialdehyde (MDA) equivalents (Ohkawa et al., 1979). Sub-samples (62.5 $\mu$ l) of tissue homogenate were treated with 25 $\mu$ of $8.1 \%$ dodecyl sulfate sodium, $187 \mu$ l of $20 \%$ trichloroacetic acid (pH 3.5) and $187 \mu \mathrm{l}$ of thiobarbituric acid. The mixture was made up to $0.5 \mathrm{ml}$ with distilled water and then heated for $60 \mathrm{~min}$ in boiling water. After cooling, $125 \mu \mathrm{l}$ of distilled water and $625 \mu \mathrm{l}$ of the mixture of n-butanol and pyridine (15: 1, v/v) were mixed and shaken vigorously before centrifugation at $4000 \mathrm{x}$ g for $10 \mathrm{~min}$. The supernatant (organic layer) was taken and its absorbance measured at $532 \mathrm{~nm}$. MDA concentrations were derived from a standard curve and the values expressed in terms of MDA nmolar equivalents per g wet wt tissue. 
Statistical Analyses

Analyses of variance (one-way ANOVA) were performed to determine agedependent effects on each biochemical parameter studied. Prior to any analysis, the data were checked for normality (Kolmogorov-Smirnov test) and homogeneity of variance (Levene's test). They were log-transformed when necessary. Significant differences were stablished at $\mathrm{p}<0.05$ level using the Least Significant Difference test (LSD test) for multiple range comparisons between pairs of the means. All statistical analyses were performed with the Statistica/ $\mathrm{W}^{\circledR} 5.0$ (StatSoft ${ }^{\mathrm{TM}}$ ) package using a PC computer.

\section{RESULTS}

\section{Antioxidant enzyme activities}

Fig. 1 shows the CAT, SOD and GPX activities of G. locusta of different ageclasses. A slight decrease in the levels of CAT was indicated in adults (12\% and $15 \%$ in male and female, respectively) with respect to the younger animals (CAT activity of juveniles and sub-adults $=19.5 \mu \mathrm{mol} \mathrm{min}^{-1} \mathrm{mg}^{-1}$ protein), but the changes were not statistically significant ( $\mathrm{p}>0.05$ ) (Fig. 1A). SOD activity was lower in sub-adults (60\% lower) and female and male adults (60 and $50 \%$ lower, respectively) compared to juveniles (juvenile SOD activity $=7.5 \mathrm{Umin}^{-1} \mathrm{mg}^{-1}$ protein; $\mathrm{p}<0.01$ ) (Fig. 1B). The activity of SOD was similar in male and female adults ( $p>0.05$ ). GPX activity also decreased in the older animals, being 65, 70 and $90 \%$ lower in respectively sub-adults, male and female adults $(\mathrm{p}<0.001)$ compared with juvenile amphipods (juvenile GPX activity $=5.5 \mathrm{nmol} \mathrm{min} \mathrm{mg}^{-1}$ protein) (Fig. 1C). GPX activity was $50 \%$ lower in females than males $(\mathrm{p}<0.001)$. 


\section{Fatty acids}

A detail description of fatty acid composition determined for the various stages

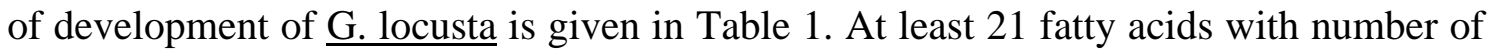
carbon atoms from 14 to 22 were present in G. locusta. A very similar pattern of lipidclasses was found in animals of all three age-classes (juveniles, sub-adults and adults). Unsaturated acids were the major fatty acids, accounting for more than $70 \%$ of total fatty acids determined in this species. Polyunsaturated fatty acids (PUFA) were the dominant unsaturated fatty acids, making up $40 \%$ of the total unsaturated fatty acids. The major components of the former were the n-3 and n-6 PUFAs, the most abundant

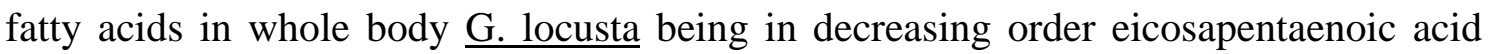
(C20:5n-3; 41 - $48 \%$ of total PUFA), arachidonic acid (C20:4n-6; 21 - $25 \%$ ) and docosahexaenoic acid (C22:6n-3; 3.5 - 6 \%). Saturated fatty acids were present at 20 to $23 \%$ of total fatty acids, and among them palmitic acid (C16:0) was the most abundant. The remaining percentage (7-10 \%) of total fatty acids includes saturated branchedchain acids (iso-C15:0, 16, 17 and anteiso C16:0) and unknown fatty acids. Besides the similarity of the lipid-classes found in the different age-classes, the concentration of each component in whole body increased with age. Thus, the concentration of total FAME (in $\mu \mathrm{g} \mathrm{mg}^{-1}$ dry wt) increased from 7.1 in juveniles to 17.0 in sub-adults to 30 in both adult males and females $(\mathrm{p}<0.001)$. In particular, the level of total polyenoic acids (PUFA), the major representative class found in this species, were up to four-fold higher in adults than in juveniles, viz. 8.2-11.9 compared to $2.7 \mu \mathrm{g} \mathrm{mg} \mathrm{g}^{-1}$ dry wt. $(\mathrm{p}<0.001)$. The total lipid content was also found to be higher in adults than in juveniles, viz. 12.813.9 compared to $7.8 \%$ of whole body wet wt. $(\mathrm{p}<0.01)$. 


\section{Lipid peroxide}

The results of lipid peroxide levels are presented in Fig. 2. Levels of whole body lipid peroxide, measured in terms of MDA, did not change among the different age-

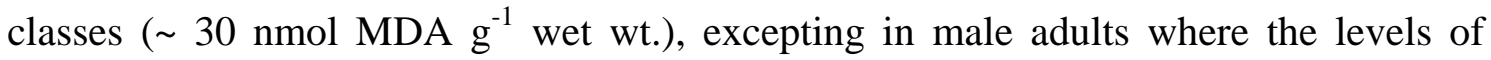
MDA were $40 \%$ higher compared to the other classes $(\mathrm{p}<0.001)$.

\section{Total protein}

The levels of total protein in the cytosol fraction of whole body $\underline{G}$. locusta were lower in both juveniles and sub-adults (about $7 \mathrm{mg} \mathrm{g}^{-1}$ wet wt.) than in adults (about 12 $\mathrm{mg} \mathrm{g}^{-1}$ wet wt.). Thus, the pattern of antioxidant enzyme activities for CAT, SOD and GPX in the different life-stages expressed as activity $\mathrm{g}^{-1}$ wet weight (data not shown) was similar to that expressed as activity $\mathrm{mg}^{-1}$ protein (Fig.1).

\section{Discussion}

The main aim of the study was to investigate aspects of pro-oxidant and antioxidant systems in amphipod crustaceans, of which little or nothing is known in many marine and estuarine species. The study was carried out on $\underline{G}$. locusta because of its current use and potential in ecotoxicological studies addressing the impact of toxicity of sediments. The work comprised a) characterisation of basal levels of antioxidant enzymes activities, fatty acid composition and peroxidation status in a laboratory population; and b) examination of age and sex-related differences in these variables over the lifetime (juveniles, sub-adults, male and female adults) of the species. 
Aerobic organisms possess a baseline status of antioxidant systems, involved in a variety of detoxication reactions, to assure the maintenance of a balance between production and removal of endogenous ROS and other pro-oxidants. This prooxidant/antioxidant balance and detoxication of potentially damaging ROS is crucial for cellular homeostasis (Winston and Di Giulio, 1991; Lemaire and Livingstone, 1993; Livingstone, 2001). G. locusta, an epibenthic amphipod living above the sediment surface (Costa and Costa, 2000), was found to possess the key antioxidant enzyme activities CAT, SOD and GPX, similar to a wide variety of other aquatic invertebrate species living under aerobic conditions, including echinoderms, molluscs, annelids and other crustaceans (Table 2). The whole body enzyme activities were determined in a laboratory population and therefore are a preliminary indication of the baseline levels in this species, since the animals were maintained under controlled conditions (oxygen, temperature, photoperiod, food) without the influence of environmental variables that are thought to contribute to the seasonal changes of antioxidant enzymes seen in many intertidal organisms (Viarengo et al., 1991a; Gamble et al., 1995; Solé et al., 1995; Buchner et al., 1996). Comparison of antioxidant enzyme activities between species is limited because of the relatively small database, the use of different units in some studies, and the unknown influence of seasonality and other factors (Table 2). However, considering the activities expressed per mg protein, SOD activity in $\underline{G}$. locusta was somewhat lower than for whole body or other tissues of two decapod crustacean species

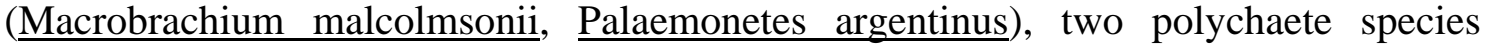
(Arenicola marina and Nereis diversicolor), the scallop Adamussium colbecki, the

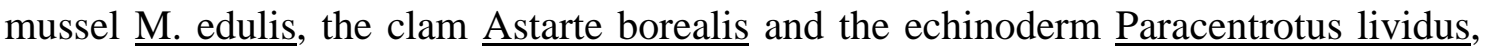
but overlapped with activities for another mytilid species $\underline{\text { M. galloprovincialis. CAT }}$ activities showed much more variability between species (up to two orders of magnitude) and those for $\underline{G}$. locusta fell somewhat in the middle of the range. Selenium- 
dependent GPX activity of $\underline{\text { G. locusta }}$ was similar, or overlapped, activities for four (M. malcolmsonii, M. edulis, M. galloprovincialis and Paracentrotus lividus) out of six species for which there was data. Sex-dependent differences in biotransformation enzyme activities, such as cytochrome P450-dependent monooxygenases, are seen in aquatic invertebrates (Livingstone, 1991), but little or nothing is known of the situation for antioxidant enzymes (Livingstone, 2001). The significance of the higher GPX activity in male than female G. locusta is therefore unknown.

ROS are continuously produced as unwanted by-products of normal oxidative metabolism, principally from mitochondrial respiration (Sohal, 1997). Therefore, intrinsic changes in oxygen consumption over an animal's lifetime can be important factors affecting age- and possibly sex-dependent differences in the antioxidant status of aquatic organisms. For example, during the course of egg and embryonic development,

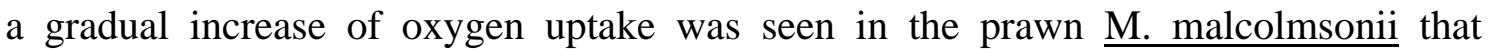
appeared to be counteracted by an increase in CAT, SOD and GPX activities (Arun and Subramanian, 1998). Similarly, SOD activity was highest in embryos of turbot

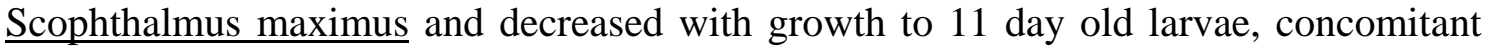
with known decreases in respiration rate over this period (Peters and Livingstone, 1996; Livingstone et al., 2001). In contrast, whole body CAT and GPX activities in $\underline{\text {. }}$ maximus increased during the same period (Peters and Livingstone, 1996). Considering a much later stage of development and growth, CAT activities and levels of other antioxidants in the mussel $\underline{\mathrm{M} \text {. edulis }}$ were lower in older than younger animals, consistent with lower oxygen consumption rates in the former (Viarengo et al., 1991b).

Changes in $\underline{G}$. locusta's physiology over its lifetime would therefore likely result in development- and/or age-related differences in its antioxidant status, as was seen for the activities of SOD and GPX (markedly lower in sub-adults and adults compared to juveniles) but not for CAT (slight decrease indicated). Considering the fact that 
metabolic rate is normally higher in juvenile than adult amphipods (Sutcliffe, 1984), the former likely require higher SOD and GPX activities to protect against potential increased production of ROS (see Table 2). Also, juveniles show faster growth rates (Pockl, 1992; Neuparth et al., 2002) or frequency of moulting cycles (Wildish, 1972; Hiwatari and Kajihara, 1988) than adult amphipods, both processes of which are associated with increased oxygen consumption. Thus at moult, several crustacean species showed an increased susceptibility to low levels of dissolved oxygen (Miller et al., 2001), which is probably related with higher oxygen consumption by the organisms

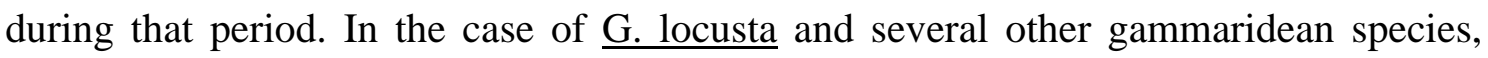
rates of oxygen uptake by individuals that had recently moulted increased two to four times over non-moult animals (see Sutcliffe, 1984). The presence of respiratory pigment (haemocyanin) in the haemolymph of $\underline{G}$. locusta may also contribute to pro-oxidant load, since release of ROS upon oxidation of respiratory pigments (Misra and Fridovich, 1972; Abele-Oeschger and Oeschger, 1995) has seen connected to the presence of high SOD activities in the polychaete $\underline{\text { Arenicola marina }}$ and the clam $\underline{\text { A. borealis }}$ (AbeleOeschger and Oeschger, 1995; Abele-Oeschger, 1996). In younger amphipod

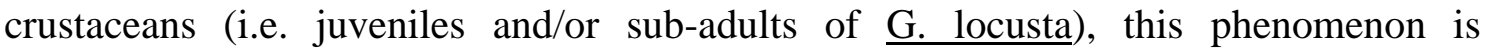
potentially very important because of an intense catabolism of haemocyanin during moulting, followed by synthesis in inter-moulting stages (Taylor and Anstiss, 1999).

The absence of age-related changes in CAT during the life cycle of $\underline{\text { G. locusta }}$ is unexpected given that marked alterations in CAT activity have been seen in aquatic invertebrates with a number of both endogenous and exogenous factors (Livingstone, 2001; also see above). Reasons for this may include that CAT activity plays a major role in preventing $\mathrm{H}_{2} \mathrm{O}_{2}$ damage in adult amphipods. Indeed, in a comparison of a large number of species, it was concluded that CAT may play a relatively more important role than GPX in detoxifying $\mathrm{H}_{2} \mathrm{O}_{2}$ in invertebrates compared to vertebrates (Livingstone et 
al., 1992). However, it must also be remembered that CAT and GPX have essentially complementary roles in $\mathrm{H}_{2} \mathrm{O}_{2}$ detoxication, having different sub-cellular localisations (peroxisomal and cytosolic, respectively), and that peroxisomes contain many specialised $\mathrm{H}_{2} \mathrm{O}_{2}$-generating endogenous enzymes such as glycolate oxidase and others (Halliwell and Gutteridge, 1999).

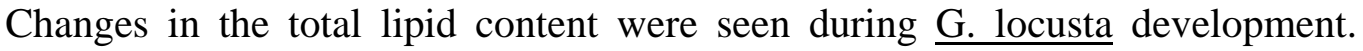
Juveniles had lower lipid levels than adults, as has also been found in the benthic amphipods Pontoporeia femorata, Monoporeia affinis (Hill et al., 1992), Macrohectopus branickii (Morris, 1984) and Diporeia hoyi (Quigley et al., 1989), which progressively accumulate lipids, in particular triacylglycerol, throughout their lifetime. Lipids accumulated in this form provide the main source of reproductive energy for amphipod adults (Clarke et al., 1985; Hill et al., 1992). With respect to fatty acid composition in amphipods, detailed information is available for various species, including the marine

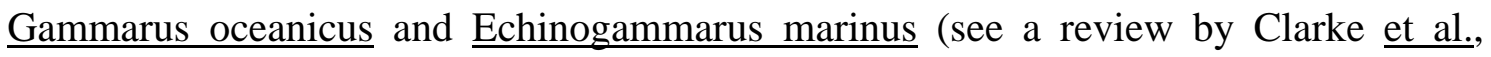
1985). In the majority of cases, using pooled samples containing mixtures of life-cycle stages and sexes, the dominant fatty acids of both phospholipid and triacylglycerol were found to be C16:0, C18:1 (n-9 and n-7 isomers), C20:5n-3 and C22:6n-3, with phospholipids tending to be more unsaturated because of greater proportions of C20:5n-3 and C22:6n-3 (Clarke et al., 1985; Kawashima, et al., 1999). The fatty acid composition found for whole body $\underline{G \text {. locusta }}$ is also characterised by a high concentration of fatty acids with a high degree of unsaturation, i.e. eicosapentaenoic (C20:5n-3) and docosahexaenoic acids (C22:6n-3). These highly unsaturated fatty acids display up to five times the oxidizability of linoleic acid (C18:2n-6), which is the most common PUFA of mammalian membranes (Cosgrove et al., 1987).

Overall, in adults of $\underline{\mathrm{G} \text {. locusta }}$ compared to juveniles, the combination of increased levels of PUFA (up to 4-fold higher), lower antioxidant enzyme activities, and 
lower metabolic rate (Sutcliffe, 1984) conserving lipid levels (Hill et al., 1992), may render the older age-class animals more susceptible to peroxidation of PUFA. This was at least indicated to be so for male (but not female) adult amphipods, which had higher levels of lipid peroxide than sub-adults and juveniles. Thus, changes in the

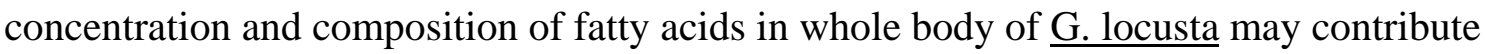
to variations in the peroxidation status of individuals over their life span. Similar incidences of variations in pro-oxidant processes during life span have been indicated for other crustaceans, e.g. lipofuscin, a pigment believed to be formed from breakdown products of peroxidized lipids, has been used as an age marker in decapods (Bluhm and Brey, 2001) and amphipods (Bluhm et al., 2001).

Despite the relative scarcity of information on the relationship between age and oxidative stress in aquatic organisms, the results for $\mathrm{G}$. locusta appear to be consistent with the general definition of ageing as "the progressive accumulation of changes that are responsible for the decreased ability of organisms to maintain physiological homeostasis, which may eventually lead to functional impairment and even death" (Tollefsbol and Cohen, 1986; review by Emerit and Chance, 1992; Yu, 1994). For instance, in studies of $\underline{\mathrm{M}}$. edulis, the lower levels of antioxidant systems in older animals appear to have resulted in an increased susceptibility to ROS and cellular damage as evidenced by respectively higher levels of MDA following re-oxygenation during recovery from anoxia (Viarengo et al., 1989), and a decreased capability to recover from copper-induced stress (Kirchin et al., 1992; Hole et al., 1993). Our data also reinforce the need to include different ages/or stages of amphipod species in toxicological tests in order to evaluate in a satisfactory manner potentially hazardous compounds during acute and chronic exposures.

In summary, this study has shown that $\underline{G}$. locusta possesses antioxidant enzyme activities capable of metabolising $\mathrm{O}_{2}{ }^{-}$(SOD) and $\mathrm{H}_{2} \mathrm{O}_{2}$ (CAT and GPX); additionally, 
although the catalytic activity was not measured, Se-dependent GPX also has the potential to metabolise organic hydroperoxides. These activities will contribute to antioxidant defences protecting against pro-oxidant processes, in particular in the immature stages of $\underline{G}$. locusta development. The decreased antioxidant enzyme activities in older amphipods, coupled with increased PUFA levels, appear to render at least the male animals more susceptible to oxidative stress, producing increased lipid peroxidation. In relation to pollution and potential application of oxidative stress measures as biomarkers in G. locusta (Correia et al., 2001; Correia et al., 2002a,b), further studies focusing on antioxidant defences versus chemical contamination are now required. However, considering that antioxidant enzyme activities represent only part of the antioxidant defence capability, and the limitations of applying the assays due to small animal biomass, it is suggested that additional and/or alternative methods would be useful in future studies, including measurement of total oxyradical scavenging capacity (Regoli and Winston, 1999) and the application of immunochemical analyses (Orbea et al., 2000).

\section{Acknowledgements}

This research was sponsored by the projects PRAXIS XXI - PCNAC/BIA /177/96 and British Council / CRUP - Treaty of Windsor, Action N ${ }^{\circ}$ B23 / 01 and fellowship PRAXIS XXI grant- BD/11022/97.

\section{References}

Abele, D., Burlando, B., Viarengo, A., Pörtner, H.O., 1998. Exposure to elevated temperatures and hydrogen peroxide elicits oxidative stress and antioxidant responses in the Antarctic intertidal limpet Nacella concinna. Comp. Biochem. Physiol. 120B, 425-435. 
Abele-Oeschger, D., 1996. A comparative study of superoxide dismutase activity in marine benthic invertebrates with respect to environmental sulphide exposure. J. Exp. Mar. Biol. Ecol. 197, 39-49.

Abele-Oeschger, D., Oeschger, R., 1995. Hypoxia-induced autoxidation of hemoglobin in the benthic invertebrates Arenicola marina (Polychaeta) and Astarte borealis (Bivalvia) and the possible effects of sulphide. J. Exp. Mar. Biol. Ecol. 187,6380.

Abele-Oeschger, D., Oeschger, R., Theede, H., 1994. Biochemical adaptations of Nereis diversicolor (Polychaeta) to temporarily increased hydrogen peroxide levels in intertidal sandflats. Mar. Ecol. Prog. Ser. 106, 101-110.

Ackman, R.G., Sipos, J.C., Jangaard, P.M., 1967. A quantification problem in the open tubular gas chromatography of fatty acid esters from cod liver lipids. Lipids 2 , 251-257.

Aebi, H., 1974. Catalase. In: Bergmayer, H.U. (Ed.), Methods of Enzymatic Analysis. Academic Press, London, pp.671-684.

Arun, S., Subramanian, P., 1998. Antioxidant enzymes in freshwater prawn Macrobrachium malcolmsonii during embryonic and larval development. Comp. Biochem. Physiol. 121B, 273-277.

Arun, S., Krishnamoorthy, P., Subramanian, P., 1999. Properties of glutathione peroxidase from the hepatopancreas of freshwater prawn Macrobrachium malcolmsonii. Inter. J. Biochem. Cell Biol. 31, 725-732.

Besten, P.J., 1998. Concepts of the implementation of biomarkers in environmental monitoring. Mar. Environ. Res. 46, 253-256. 
Bligh, E.G., Dyer, W.J., 1959. A rapid method of total lipid extraction and purification. Can. J. Biochem. Physiol. 37, 911-917.

Bluhm, B.A., Brey, T., 2001. Age determination in the Antarctic shrimp Notocrangon antarcticus (Crustacea: Decapoda), using the autofluorescent pigment lipofuscin. Mar. Biol. 138, 247-257.

Bluhm, B.A., Brey, T., Klages, M., 2001. The autofluorescent age pigment lipofuscin: key to age, growth and productivity of the Antarctic amphipod Waldeckia obesa (Chevreux, 1905). J. Exp. Mar. Biol. Ecol. 258, 215-235.

Bradford, M.M., 1976. A rapid and sensitive method for the quantitation of microgram quantities of protein utilizing the principle of protein-dye binding. Anal. Biochem. 72, 248-254.

Buchner, T., Abele-Oeschger, D., Theede, H., 1996. Aspects of antioxidant status in the polychaete Arenicola marina: tissue and subcellular distribution, and reaction to environmental hydrogen peroxide and elevated temperatures. Mar. Ecol. Prog. Ser. 143, 141-150.

Clarke, A., Skadsheim, A., Holmes, L.J., 1985. Lipid biochemistry and reproductive biology in two species of Gammaridae (Crustacea: Amphipoda). Mar. Biol. 88, 247-263.

Correia, A.D., Costa, F.O., Neuparth, T., Diniz, M.E., Costa, M.H., 2001. Sublethal effects of copper-spiked sediments on the marine amphipod Gammarus locusta: evidence of hormesis? Ecotoxicol. Environ. Rest. 4(2), 32-39 (available online http://www.uc.pt/eer/mainpage.htm). 
Correia, A.D., Lima, G., Costa, M.H., Livingstone, D.R., 2002a. Biomarkers of copper exposure and toxicity in a marine amphipod Gammarus locusta (Crustacea): I. Induction of metallothionein and lipid peroxidation. Biomarkers 7, 422-437.

Correia, A.D., Livingstone, D.R., Costa, M.H., 2002b. Effects of water-borne copper on metallothionein and lipid peroxidation in the marine amphipod Gammarus locusta. Mar. Environ. Res. 54, 357-360.

Cosgrove, J.P., Church, D.F., Pryor, W.A., 1987. The kinetics of the autoxidation of polyunsaturated fatty acids. Lipids 22, 299-304.

Costa, F.O., Correia, A.D., Costa, M. H., 1998. Acute marine sediment toxicity: A potential new test with the amphipod Gammarus locusta. Ecotoxicol. Environ. Saf. 40, 81-87.

Costa, F.O., Costa, M.H., 2000. Review of the ecology of Gammarus locusta (L.). Polsk. Arch. Hydrobiol. 47, 541-559.

De Witt; Redmond, M.S., Sewall, J.E., Swartz, R.C. (Eds.), 1992. Development of a chronic sediment toxicity test for marine benthic amphipods. US. Environmental Protection Agency for the Chesapeake Bay Program. Newport.

Di Giulio, R.T., Benson, W.H., Sanders, B.M., Van Veld, P.A., 1995. Biochemical mechanisms: metabolism, adaptation, and toxicity. In Rand, G. (Ed.), Fundamentals of Aquatic Toxicology, Effects, Environmental Fate, and Risk Assessment, Taylor \& Francis, London, pp. 523-561.

Emerit, I, Chance, B. (Eds.), 1992. Free radicals and aging. Birkhãuser Verlag, Basel. 
Gamble, S., Goldfarb, P.S., Porte, C., Livingstone, D.R., 1995. Glutathione peroxidase and other antioxidant enzyme function in marine invertebrates (Mytilus

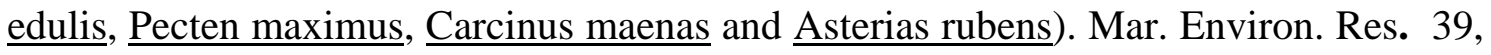
191-195.

Günzler, W.A., Flohe, L., 1985. Glutathione Peroxidase. In Greenwald, R.A. (Ed.), Handbook of methods for oxygen research, CRC- Press, Boca Raton, FL, pp. 285-265.

Halliwell, B., Gutteridge, J.M.C., (Eds.) 1999. Free radicals in Biology and Medicine. Oxford University Press, Oxford.

Hill, C., Quingley, M.A., Cavaletto, J.F., Gordon, W., 1992. Seasonal changes in lipid content and composition in the benthic amphipods Monoporeia affinis and Pontoporeia femorata. Limnol. Oceanogr. 37,1280-1289.

Hiwatari, T., Kajihara, T., 1988. Experimental studies on the growth and breeding of Hyale barbicornis (Amphipoda, Crustacea) at different temperatures. Nippon Suisan Gakkaishi 54, 39-43.

Hole, L.M., Moore, M.N., Bellany, D., 1993. Age-related cellular reactions to copper in the marine mussel Mytilus edulis. Mar. Ecol. Prog. Ser. 94, 175-179.

Kawashima, H., Takeuchi, I., Ohnishi, M., 1999. Fatty acid compositions in four of caprellid amphipod species (Crustacea) from Otsuchi and Mutsu Bays in Northern Japan. J. Jpn.Oil. Soc. 48, 23-27. 
Kirchin, M.A., Moore, M.N., Dean, R.T., Winston, G.W., 1992. The role of oxyradicals in intracellular proteolysis and toxicity in mussels. Mar. Environ. Res. 34, 315-320.

Lemaire, P., Livingstone, D.R., 1993. Pro-oxidant/antioxidant processes and organic xenobiotic interactions in marine organisms, in particular the flounder

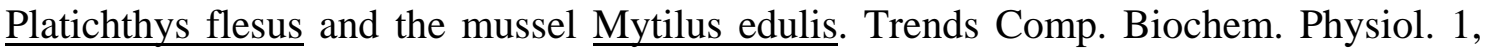
$1119-1150$

Livingstone, D.R., 1991. Organic xenobiotic metabolism in marine invertebrates. Adv. Comp. Environ. Physiol. 7, 45-185.

Livingstone, D.R., 2001. Contaminated-stimulated reactive oxygen species production and oxidative damage in aquatic organisms. Mar. Pollut. Bull. 42, 656-666.

Livingstone, D.R., Chipman, J.K., Lowe, D.M., Minier, C., Mitchelmore, C.L., Moore, M.N., Peters, L.D., Pipe, R.K., 2000. Development of biomarkers to detect the effects of organic pollution on aquatic invertebrates: recent molecular, genotoxic, cellular and immunological studies on the common mussel (Mytilus edulis L.) and other mytilids. Inter. J. Pollut. 13, 56-91.

Livingstone, D.R., Garcia-Martinez, P., Michel, X., Narbonne, J.F., O’Hara, S., Ribera, D.,Winston, G.W., 1990. Oxyradical production as a pollution-mediated mechanism of toxicity in the common mussel, Mytilus edulis L., and other molluscs. Functional Ecology 4, 415-424.

Livingstone, D.R., Lips, F., Martinez, P.G., Pipe, R.K., 1992. Antioxidant enzymes in the digestive gland of the common mussel Mytilus edulis. Mar. Biol. 112, 265-276. 
Livingstone, D.R., O'Hara, S.C.M., Frettsome, F., Rundle, J., 2001. Contaminant-mediated pro-/anti-oxidant processes and oxidative damage in early lifestages of fish. In Atkinson D. and Thorndyke M. (Eds.), Environment and Animal Development. Genes, life histories and plasticity, BIOS Scientific Publishers, Oxford, pp. 173-201.

McCord, J.M., Fridovich, I., 1969. Superoxide dismutase: An enzymatic function for erythrocuprein (hemocuprein). J. Biol. Chem. 244, 6049-6055.

Metcalfe, L.D., Schmitz, A.A., 1961. The rapid preparation of fatty acid esters for gas chromatographic analysis. Analyt. Chem. 33, 363.

Miller, D.C., Poucher, S.L., Coiro, L., 2001. Determination of lethal dissolved oxygen levels for selected marine and estuarine fishes, crustaceans, and a bivalve. Mar. Biol. 140, 287-296.

Misra, H.P., Fridovich I., 1972. The generation of superoxide radical during the autoxidation of haemoglobin. J. Biol. Chem. 247, 6960-6962.

Morris, R.J., 1984. The endemic faunae of lake Baikal: Their general biochemistry and detailed lipid composition. Proc. R. Soc. Lond. Ser. B 222, 51-78.

Mucha, A.P., Costa, M.H., 1999. Macrozoobenthic community structure in two Portuguese estuaries: Relationship with organic enrichment and nutrient gradients. Acta Oecologica 20, 363-373.

Neuparth, T., Costa, F.O., Costa, M.H., 2002. Effects of temperature and salinity on life history of the marine amphipod Gammarus locusta. Implications for ecotoxicological testing. Ecotoxicology 11, 55-67. 
Neves, C.A., Santos, E.A., Bainy, C.D., 2000. Reduced superoxide activity in

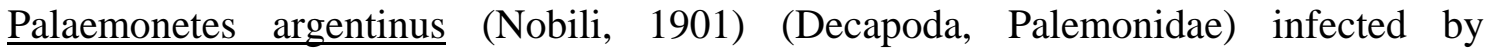
Probopyrus ringueleti (Verdi \& Shuldt, 1987) (Isopoda, Bopyridae). Deseases Aquatic. Organis. 39, 155-158.

Ni, W., Trelease, R.N., Eising, R., 1990. Two temporally synthesized charge subunits interact to form the five isoforms of cottonseed (Gossypium hirsutum) catalase. Biochem J. 269, 233-238.

Ohkawa, H., Ohishi, N., Yagi, K., 1979. Assay for lipid peroxides in animal tissues by thiobarbituric acid reaction. Anal. Biochem. 95, 351-358.

Orbea, A., Fahimi, H.D., Cajaraville, M.P., 2000. Immunolocalization of four antioxidant enzymes in digestive gland of molluscs and crustaceans and in fish liver. Histochem. Cell Biol. 114, 393-404.

Parihar, M.S., Dubey, A.K., 1995. Lipid peroxidation and ascorbic acid status in respiratory organs of male and female freshwater catfish Heteropneustes fossils exposed to temperature increase. Comp. Biochem. Physiol. 112C, 309-313.

Perez-Trigo, E., Garcia-Martinez, P., Catoira, J.L., Mosquera, G., 1995. Subcellular distribution of antioxidant enzymes in the gonads of the sea urchin, Paracentrotus lividus Lmk, from the Ría Ares-Betanzos, NW Spain. Echinoderm Research 8, 51-55.

Peters, L.D., Livingstone, D.R., 1996. Antioxidant enzyme activities in embryologic and early larval stages of turbot. J. Fish. Biol. 49, 986-997. 
Peters, L.D., Porte, C. Albaigés, J., Livingstone, D.R., 1994. 7-Ethoxyresorufin O-deethylase (EROD) activity and antioxidant enzyme activities in larvae of sardine (Sardina pilchardus) from the north coast of Spain. Mar. Pollut. Bull. 28, 299-304.

Pockl, M., 1992. Laboratory studies on growth, feeding, moulting and mortality in the freshwater amphipods Gammarus fossarum and G. roeseli. Arch. Hydrobiol., 134, 223-253.

Quigley, M.A., Cavaletto, J.F., Gardner, W.S., 1989. Lipid composition related to size and maturity of the amphipod Pontoporeia hoyi. J. Great Lakes Res. 15, 601-610.

Regoli, F., Nigro, M., Principato, G., Orlando, E., 1997. Defenses against oxidative stress in the Antarctic scallop Adamussium colbecki and effects of acute exposure to metals. Hydrobiologia 355, 139-144.

Regoli, F., Winston, G.W., 1999. Quantification of total oxidant scavenging capacity of antioxidants for peroxynitrite, peroxyl radicals, and hydroxyl radicals. Toxicol. Appl. Pharmacol. 156, 96-105.

Reish, D.J., 1993. Effects of metals and organic compounds on survival and bioaccumulation in two species of marine gammaridean amphipod, together with a summary of toxicological research on this group. J. Nat. Hist. Lond. 27, 781-794.

Ringwood, A.H., Conners, D.E., 2000. The effects of glutathione depletion on reproductive success in oysters, Crassostrea virginica. Mar. Environ. Pollut. 50, 207211.

Saint-Denis, M., Labrot, F., Narbonne, J.F., Ribera, D., 1998. Glutathione, glutathione-related enzymes, and catalase activities in the earthworm Eisenia fetida andrei. Arch. Environ. Contam. Toxicol. 35, 602-614. 
Sohal, R.S., 1997. Mitochondria generate superoxide anion radicals and hydrogen peroxide. FASEB J. 11, 1269.

Solé, M., Porte, C., Albaigés, J., 1995. Seasonal variation in the mixed-function oxygenase system and antioxidant enzymes of the mussel Mytilus galloprovincialis. Environ. Toxicol. Chem. 14, 157-164.

Sutcliffe, D.W., 1984. Quantitative aspects of oxygen uptake by Gammarus (Crustacea, Amphipoda): a critical overview. Freshwater Biology 14, 443-489.

Taylor, H.H., Anstiss, J.M., 1999. Copper and haemocyanin dynamics in aquatic invertebrates. Mar. Fresh. Res. 50, 907-931.

Tollefsbol, T.O., Cohen, H.J., 1986. Expression of intracellular biochemical defects of lymphocytes in aging: proposal of a general aging mechanism which is not cell-specific. Exp. Gerontol. 21, 129-148.

Torreiro, M.F., 1995. Enzimas antioxidants en el contenido digestivo del erizo de mar, Paracentrotus lividus LmK., de las Costas Gallegas. Tesina de Licenciatura, Universidade de Santiago de Compostela, Dep. de Bioquímica Y Biología Molecular, Santiado de Compostela, 83 p.

Viarengo, A., Canesi, L., Pertica, M., Livingstone, D.R., 1991a. Seasonal variations in the antioxidant defence systems and lipid peroxidation of the digestive gland of mussels. Comp. Biochem. Physiol. 100C, 187-190.

Viarengo, A., Canesi, L., Pertica, M., Livingstone, D.R., Orunesu, M., 1991b. Age-related lipid peroxidation in the digestive gland of mussels: The role of the antioxidant defence systems. Experientia 47, 454-457. 
Viarengo, A., Pertica, M., Canesi, L., Accomando, R., Mancinelli, G., Orunesu, M., 1989. Lipid peroxidation and level of antioxidant compounds (GSH, Vitamin E) in the digestive glands of mussels of three different age groups exposed to anaerobic and aerobic conditions. Mar. Environ. Res. 28, 291-295.

Wildish, D.J., 1972. Post embryonic growth and age in some littoral Orchestia (Amphipoda, Talitridae). Crustaceana 3, 267-274.

Winston, G.W., Di Giulio, R.T., 1991. Prooxidant and antioxidant mechanisms in aquatic organisms. Aquat. Toxicol. 19, 137-161.

Yu, B.P., 1994. Cellular defenses against damage from reactive oxygen species. Physiol. Rev. 74, 139-162. 
Fig. 1- Activity of catalase (A), superoxide dismutase (SOD) (B) and glutathione peroxidase (GPX) (C) in the whole body of Gammarus locusta of different ages. The values are expressed as mean $\pm \mathrm{SD}$ (number of pools, $\mathrm{n}=3$ to 5 ). ${ }^{* *}$ Indicates significant differences from juveniles $(\mathrm{p}<0.01)$; *** Indicates significant differences from juveniles $(\mathrm{p}<0.001)$.

Fig. 2- Levels of lipid peroxide in the whole body of Gammarus locusta of different age-classes. The values are expressed as mean \pm SD (number of pools, $\mathrm{n}=4$ to 5 ). ${ }^{* *}$ Indicates significant differences from juveniles $(\mathrm{p}<0.01)$. 

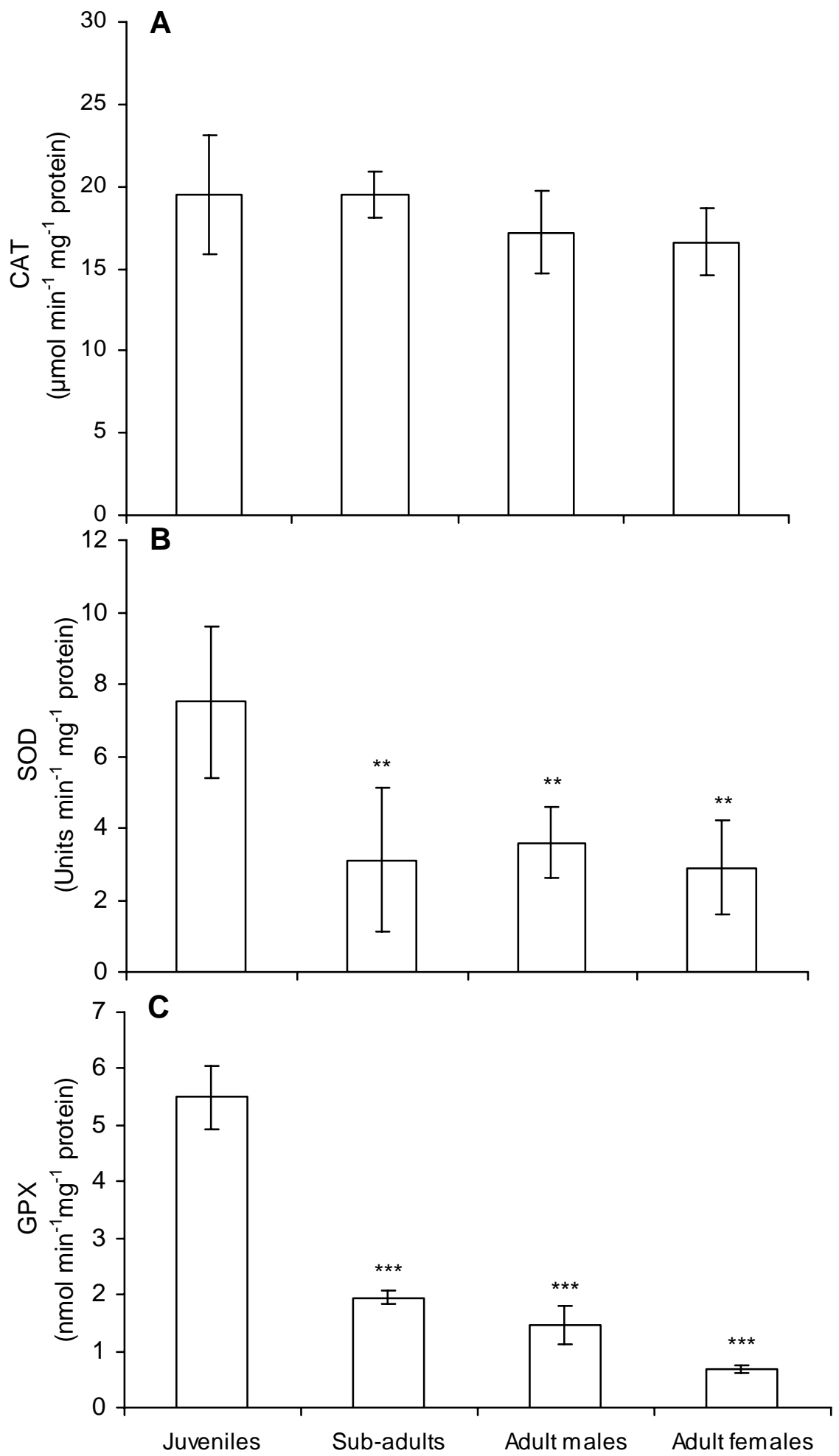


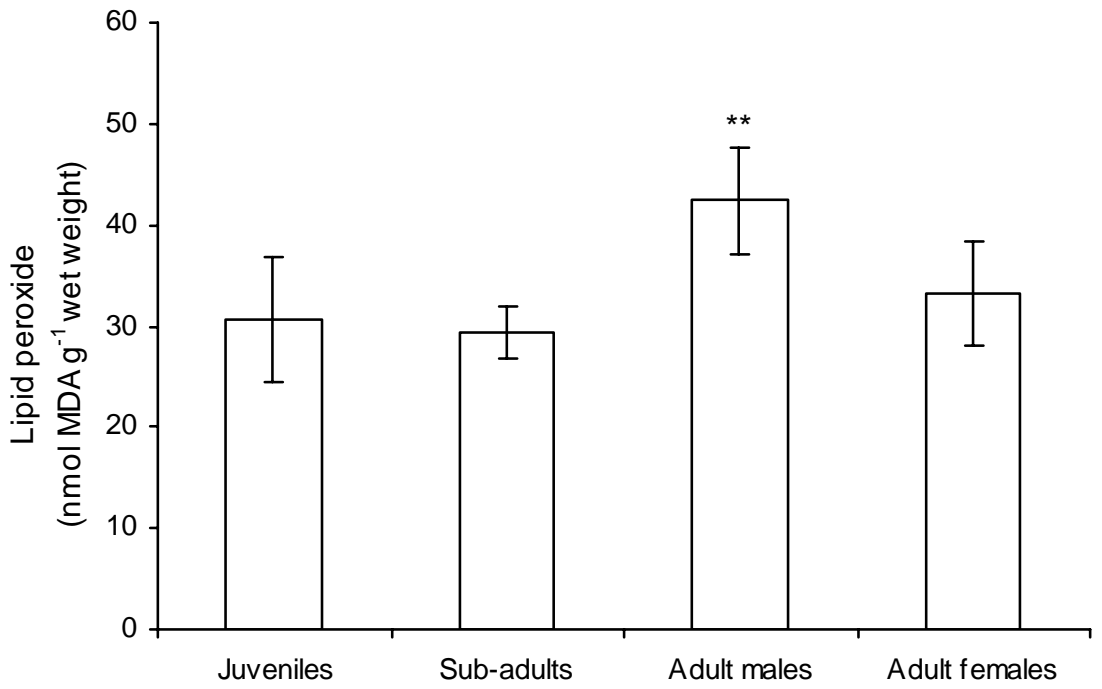


Table 1- Fatty acid composition determined for different age-classes of Gammarus locusta. The values are expressed as $\mu \mathrm{g}$ fatty acid $\mathrm{mg}^{-1}$ whole body dry wt. Data are means of three different samples. -: not detected; tr: trace $(<1 \%)$. ${ }^{* *}$ Indicates significant differences from juveniles $(\mathrm{p}<$ $0.01) ; * * *$ Indicates significant differences from juveniles $(\mathrm{p}<0.001)$.

\begin{tabular}{|c|c|c|c|c|}
\hline FATTY ACID & Juveniles & Sub-adults & Adult males & Adult females \\
\hline C14:0 & $\operatorname{tr}$ & $\operatorname{tr}$ & $\operatorname{tr}$ & 0.19 \\
\hline C15:0 & $\operatorname{tr}$ & 0.15 & 0.2 & 0.25 \\
\hline C16:0 & 1.11 & 2.62 & 5.04 & 5.47 \\
\hline C17:0 & --- & --- & 0.5 & 0.20 \\
\hline C18:0 & 0.27 & 0.55 & 0.75 & 0.85 \\
\hline C20:0 & $\operatorname{tr}$ & $\operatorname{tr}$ & 0.14 & $\operatorname{tr}$ \\
\hline C14:1n-5 & $\operatorname{tr}$ & $\operatorname{tr}$ & tr & 0.08 \\
\hline C16:1n-7 & 0.29 & 0.44 & 0.37 & 1.11 \\
\hline C16:1n-5 & $\operatorname{tr}$ & $\operatorname{tr}$ & $\operatorname{tr}$ & 0.09 \\
\hline C18:1n-9 & 0.94 & 2.43 & 5.18 & 6.54 \\
\hline C18:1n-7 & 0.52 & 1.25 & 1.53 & 2.21 \\
\hline C18:1n-5 & $\operatorname{tr}$ & $\operatorname{tr}$ & $\operatorname{tr}$ & $\operatorname{tr}$ \\
\hline C20:1n-7 & $\operatorname{tr}$ & $\operatorname{tr}$ & $\operatorname{tr}$ & 0.19 \\
\hline C22:1n-11 & 0.16 & 0.29 & 0.13 & 0.45 \\
\hline C22:1n-9 & $\operatorname{tr}$ & --- & --- & --- \\
\hline C16:2n-4 & 0.11 & 0.22 & 0.44 & 0.45 \\
\hline C18:2n-6 & 0.24 & 0.93 & 1.72 & 1.48 \\
\hline C20:2n-6 & $\operatorname{tr}$ & $\operatorname{tr}$ & 0.18 & 0.12 \\
\hline C18:3n-3 & 0.10 & 0.61 & 0.75 & 0.99 \\
\hline C18:4n-3 & $\operatorname{tr}$ & 0.19 & 0.20 & 0.54 \\
\hline C20:3n-6 & $\operatorname{tr}$ & 0.15 & 0.20 & 0.16 \\
\hline C20:4n-6 & 0.55 & 1.45 & 3.03 & 1.70 \\
\hline C20:3n-3 & 0.01 & $\operatorname{tr}$ & 0.10 & 0.09 \\
\hline C20:4n-3 & $\operatorname{tr}$ & 0.27 & 0.20 & 0.28 \\
\hline$C 20: 5 n-3$ & 1.30 & 2.92 & 5.51 & 3.35 \\
\hline C21:5n-3 & $\operatorname{tr}$ & --- & --- & --- \\
\hline C22:5n-6 & $\operatorname{tr}$ & 0.11 & 0.12 & 0.08 \\
\hline C22:5n-3 & 0.09 & 0.39 & 0.72 & 0.51 \\
\hline C22:6n-3 & 0.49 & 0.70 & 1.03 & 0.53 \\
\hline Iso C15:0 & $\operatorname{tr}$ & --- & --- & $\operatorname{tr}$ \\
\hline Iso C16:0 & $\operatorname{tr}$ & $\operatorname{tr}$ & $\operatorname{tr}$ & $\operatorname{tr}$ \\
\hline Anteiso C16:0 & $\operatorname{tr}$ & $\operatorname{tr}$ & 0.27 & $\operatorname{tr}$ \\
\hline Iso $\mathrm{C} 17: 0$ & $\operatorname{tr}$ & $\operatorname{tr}$ & 0.10 & $\operatorname{tr}$ \\
\hline \multicolumn{5}{|l|}{ Totals: } \\
\hline $\begin{array}{l}\text { saturated } \\
\text { unsaturated }\end{array}$ & $\begin{array}{l}1.50 \pm 0.04 \\
5.25 \pm 0.19\end{array}$ & $\begin{array}{r}3.42 \pm 0.44 \\
12.88 \pm 1.45^{* * *}\end{array}$ & $\begin{array}{c}6.53 \pm 1.56 \\
21.83 \pm 5.47^{* * *}\end{array}$ & $\begin{array}{l}0.92 \pm 0.4 / \\
21.25 \pm 0.87^{* * *}\end{array}$ \\
\hline unsat.: sat. & 3.5 & 3.8 & 3.3 & 3.1 \\
\hline monoenoic & $2.13 \pm 0.04$ & $4.78 \pm 0.60^{* * *}$ & $7.63 \pm 1.98^{* * *}$ & $10.98 \pm 0.59^{* * *}$ \\
\hline diienoic & $0.39 \pm 0.04$ & $1.24 \pm 0.20^{* * *}$ & $2.34 \pm 0.55^{* * *}$ & $2.05 \pm 0.08^{* * *}$ \\
\hline Polyenoic (PUFA) & $2.73 \pm 0.12$ & $6.86 \pm 0.66^{* * *}$ & $11.86 \pm 2.95^{* * *}$ & $8.22 \pm 0.28^{* * *}$ \\
\hline Total FAME & $7.05 \pm 0.25$ & $16.98 \pm 1.96^{* * *}$ & $29.99 \pm 7.32^{* * *}$ & $29.64 \pm 1.59^{* * *}$ \\
\hline Total lipid (\% of wet weight) & $7.78 \pm 1.63$ & $8.98 \pm 0.94$ & $13.91 \pm 1.37^{* * *}$ & $12.76 \pm 1.13^{* *}$ \\
\hline
\end{tabular}


Table 2- Specific activities of antioxidant enzymes as found in the current study, as well as in other invertebrates species from the literature.

-: not analysed; nd: no data given.

\begin{tabular}{|c|c|c|c|c|c|c|c|}
\hline \multirow[b]{2}{*}{$\begin{array}{l}\text { Taxonomic group } \\
\text { and species }\end{array}$} & \multirow[b]{2}{*}{$\begin{array}{l}\text { Age/ } \\
\text { Length }\end{array}$} & \multirow[b]{2}{*}{ Tissue } & \multicolumn{5}{|c|}{ GPX } \\
\hline & & & $\begin{array}{c}\text { SOD } \\
\mathrm{Umin}^{-1} \mathrm{mg}^{1} \text { prot. }\end{array}$ & $\underset{\mu \mathrm{mol} \mathrm{min}^{1} \mathrm{mg}^{1} \text { prot. }}{\text { CAT }}$ & $\begin{array}{l}\text { Total-GPX } \\
\text { nmol min }\end{array}$ & $\begin{array}{l}\text { Se-dependent } \\
{ }^{-1} \mathrm{mg}^{-1} \text { prot. }\end{array}$ & References \\
\hline \multicolumn{8}{|l|}{ Crustacea } \\
\hline \multicolumn{8}{|l|}{ - Decapoda } \\
\hline \multirow[t]{3}{*}{ Macrobrachium malcolmsonii } & Adults & Digestive gland & --- & --- & 11.0 & --- & Arun et al. (1999) \\
\hline & Sub-adults & Digestive gland & $26 \pm 0.1$ & $49 \pm 0.8$ & $9.4 \pm 0.1$ & $1.6 \pm 0.002$ & Arun and Subramanian, (1998) \\
\hline & Larvae & Whole body & $32 \pm 0.7$ & $33 \pm 0.7$ & $5.9 \pm 0.2$ & $0.1 \pm 0.01$ & Arun and Subramanian, (1998) \\
\hline \multirow{2}{*}{$\frac{\text { Palaemonetes argentinus }}{\underline{\text { Carcinus maenas }}}$} & Adults & Whole body & $30-40$ & $1-9.5$ & 1- 8 & --- & Neves et al. (2000) \\
\hline & Adults & Digestive gland & $173 \pm 10^{\mathrm{a}}$ & $0.28 \pm 0.1^{\mathrm{b}}$ & $148 \pm 17^{c}$ & $31 \pm 10^{c}$ & Gamble et al. (1995) \\
\hline \multicolumn{8}{|l|}{ - Amphipoda } \\
\hline \multirow[t]{4}{*}{$\underline{\text { Gammarus locusta }}$} & Adults & Whole body & M $3.6 \pm 1.0$ & M $17.1 \pm 2.5$ & --- & M $1.5 \pm 0.3$ & Current study \\
\hline & Adults & Whole body & F $\quad 2.9 \pm 1.3$ & F $\quad 16.6 \pm 2.0$ & --- & F $0.7 \pm 0.07$ & Current study \\
\hline & Sub-adults & Whole body & $3.1 \pm 2.0$ & $19.5 \pm 1.4$ & --- & $1.95 \pm 0.1$ & Current study \\
\hline & Juveniles & Whole body & $7.5 \pm 2.1$ & $19.5 \pm 3.6$ & --- & $5.5 \pm 0.6$ & Current study \\
\hline \multicolumn{8}{|l|}{ Mollusca } \\
\hline \multicolumn{8}{|l|}{ - Bivalvia } \\
\hline Mytilus edulis & Adults & Digestive gland & $12 \pm 1.5$ & $189 \pm 21$ & $7.7 \pm 0.4$ & $2.4 \pm 0.1$ & Livingstone et al. (1992) \\
\hline & Adults & Digestive gland & $615 \pm 52^{\mathrm{a}}$ & $5.9 \pm 1.1^{b}$ & $604 \pm 146^{\mathrm{c}}$ & $479 \pm 203^{c}$ & Gamble et al. (1995) \\
\hline & Adults & Digestive gland & $569 \pm 218^{\mathrm{a}}$ & $1.09 \pm 0.1^{\mathrm{b}}$ & $465 \pm 125^{\mathrm{c}}$ & $113 \pm 40^{c}$ & Viarengo et al. (1991b) \\
\hline & 6-8 years & Digestive gland & $584 \pm 225^{\mathrm{a}}$ & $0.95 \pm 0.1^{\mathrm{b}}$ & $545 \pm 138^{\mathrm{c}}$ & $115 \pm 79^{c}$ & Viarengo et al. (1991b) \\
\hline & 2-4 years & Digestive gland & $593 \pm 86^{\mathrm{a}}$ & $1.4 \pm 0.08^{\mathrm{b}}$ & $661 \pm 150^{c}$ & $121 \pm 34^{\mathrm{c}}$ & Viarengo et al. (1991b) \\
\hline Mytilus galloprovincialis & Adults & Digestive gland & $6-13$ & $2.5-4.0^{\mathrm{b}}$ & -- & $2.4-3.7$ & Solé et al. (1995) \\
\hline Pecten maximus & nd & Digestive gland & $324 \pm 6^{a}$ & $36.1 \pm 0.6^{b}$ & $450 \pm 151^{c}$ & $260 \pm 135^{c}$ & Gamble et al. (1995) \\
\hline$\overline{\text { Astarte borealis }}$ & nd & Gills & $11.1 \pm 4.1$ & $134.6 \pm 44$ & --- & --- & $\begin{array}{c}\text { Abele-Oeschger and Oeschger } \\
\text { (1995) }\end{array}$ \\
\hline Adamussium colbecki & nd & Digestive gland & $12.9 \pm 1.7$ & $444-715$ & $8.3-23.7$ & $5.7-11.9$ & Regoli et al. (1997) \\
\hline
\end{tabular}

${ }^{\mathrm{a}}$ Units $\mathrm{g}^{-1}$ wet wt.; ${ }^{\mathrm{b}} \mathrm{mmol} \mathrm{min}^{-1} \mathrm{~g}^{-1}$ wet wt.; ${ }^{\mathrm{c}} \mathrm{nmol} \mathrm{min}^{-1} \mathrm{~g}^{-1}$ wet wt. 
Table 2- Continued.

\begin{tabular}{|c|c|c|c|c|c|c|c|}
\hline \multirow[b]{2}{*}{$\begin{array}{l}\text { Taxonomic group } \\
\text { and species }\end{array}$} & \multirow[b]{2}{*}{$\begin{array}{l}\text { Age/ } \\
\text { Length }\end{array}$} & \multirow[b]{2}{*}{ Tissue } & \multicolumn{5}{|c|}{ GPX } \\
\hline & & & $\underset{U_{m_{i n}}^{-1} \mathrm{mg}^{-1} \text { prot }}{\text { SOD }}$ & $\underset{\mu \mathrm{mol} \mathrm{min}^{-1} \mathrm{mg}^{1} \text { prot }}{\text { CAT }}$ & $\begin{array}{l}\text { Total-GPX } \\
\text { nmol min }\end{array}$ & $\begin{array}{l}\text { Se-dependent } \\
{ }^{-1} \mathrm{mg}^{-1} \text { prot. }\end{array}$ & References \\
\hline \multicolumn{8}{|l|}{ Echinodermata } \\
\hline \multicolumn{8}{|l|}{ • Echinoidea } \\
\hline \multirow[t]{2}{*}{$\underline{\text { Paracentrotus lividus }}$} & $\begin{array}{c}42-60 \mathrm{~mm} \\
\text { diameter }\end{array}$ & Digestive gland & $11.62 \pm 0.50$ & $1970 \pm 120$ & $9.6 \pm 0.58$ & $2.11 \pm 0.22$ & Torreiro (1995) \\
\hline & $\begin{array}{c}60 \mathrm{~mm} \\
\text { diameter }\end{array}$ & Gonads & $162 \pm 9^{\mathrm{a}}$ & $83 \pm 8^{b}$ & $231.5 \pm 11^{\mathrm{c}}$ & $75.1 \pm 3.4^{c}$ & Perez-Trigo et al. (1995) \\
\hline \multicolumn{8}{|l|}{ - Asteroidea } \\
\hline Asterias rubens & $\begin{array}{l}12 \mathrm{~cm} \\
\text { diameter }\end{array}$ & Digestive gland & $185 \pm 9^{\mathrm{a}}$ & $20 \pm 0.6^{\mathrm{b}}$ & $1040 \pm 131^{c}$ & $554 \pm 139^{c}$ & Gamble et al. (1995) \\
\hline \multicolumn{8}{|l|}{ Annelida } \\
\hline \multicolumn{8}{|l|}{ - Polychaeta } \\
\hline \multirow[t]{2}{*}{ Arenicola marina } & Adults & Chloragog tissues & $11-26$ & $320-1373$ & --- & --- & $\begin{array}{l}\text { Abele-Oeschger and } \\
\text { Oeschger (1995) }\end{array}$ \\
\hline & Juveniles & Chloragog tissues & $20-35$ & $240-976$ & --- & --- & Buchner et al. (1996) \\
\hline - Oligochaeta & nd & Whole body & 9 & $80-199$ & --- & --- & Abele-Oeschger et al. (1994) \\
\hline Eisenia fetida & Adults & Whole body & --- & $67 \pm 18$ & $43 \pm 18$ & $30 \pm 7$ & Saint-Denis et al. (1998) \\
\hline
\end{tabular}

${ }^{a}$ Units $\mathrm{g}^{-1}$ wet wt.; ${ }^{\mathrm{b}} \mathrm{mmol} \mathrm{min}^{-1} \mathrm{~g}^{-1}$ wet wt.; ${ }^{\mathrm{c}} \mathrm{nmol} \mathrm{min}^{-1} \mathrm{~g}^{-1}$ wet wt. 